\title{
PERKEMBANGAN EPISTEMOLOGI DAN INSTITUSI PERGURUAN TINGGI ISLAM INDONESIA
}

\author{
Tiy Kusmarrabbi Karo \\ Program Studi Pendidikan Bahasa Arab STAI As-Sunnah Deli Serdang \\ Jl. Medan-Tg. Morawa, Km. 13 G. Darmo, Desa B. Sari, Kec. Tg. Morawa Kab. Deli Serdang \\ Kusma70@yahoo.co.id
}

\begin{abstract}
Abstrak: Dinamika Perguruan Tinggi Isam Indonesia mempunyai tingkatan perkembangan, yaitu: pertama, berbentuk sekolah tinggi, termasuk didalamnya jenis pendidikan tinggi: Sekolah Tinggi Islam (STI), Perguruan Tinggi Agama Islam Negeri (PTAIN), Akademi Dinas Ilmu Agama (ADIA) dan terakhir Sekolah Tinggi Agama Islam Negeri (STAIN). Pada fase ini kelompok keilmuan dikembangkan satu disiplin ilmu keislaman. Kelompok kedua, adalah bentuk institut, di sini pengembangan keilmuannya lebih meluas dari kelompok pertama, lembaga inilah yang bernama Institut Agama Islam Negeri (IAIN), di lembaga ini dikembangkan sekelompok ilmu sejenis yang dalam hal ini ilmu-ilmu keagamaan Islam. Ketiga, adalah berbentuk universitas, pada lembaga ini akan dikembangkan sejumlah disiplin ilmu yang mencakup: ilmu-ilmu kealaman, ilmu-ilmu sosial, humaniora, dan ilmu-ilmu keagamaan. Kehadiran Universitas Islam Negeri Sumatera Utara (UIN SU) akan bisa memberikan kontribusinya bagi pembentukan sumber daya manusia yang cekatan yang dapat berkiprah di era global, dimana salah satu ciri era global adalah kompetitif. Tulisan ini akan mencoba mendeskripsikan hal-hal berikut; Perkembangan Institusional Perguruan Tinggi Islam Indonesia IAIN, STAI, dan UIN, Perbedaan Mendasar antara STAIN, IAIN, dan UIN pada tataran epistemologia dan struktural kelembagaan, Studi Kasus Satu UIN, yaitu UIN SU Medan: Perkembangan (data statistik), Tantangan dan Peluang.
\end{abstract}

Kata Kunci : Perkembangan, Epistemologi, Perguruan Tinggi Islam, Indonesia

\section{Pendahuluan}

Pendidikan tinggi Islam di Indonesia telah berlangsung sejak dibukanya Sekolah Tinggi Islam (STI) di Jakarta pada bulan Juli 1945 menjelang Indonesia merdeka. Sejak saat itu dinamika dan perkembangan Pendidikan Tinggi Islam dimulai. Setelah terbentuknya STI berubah menjadi UII (Universitas Islam Indonesia). Perkembangan berikutnya fakultas agama UII dinegerikan menjadi PTAIN (Perguruan Tinggi Agama Islam Negeri), kemudian fase berikutnya 
muncullah IAIN dan STAIN, selain itu muncul pula pendidikan tinggi Islam swasta, baik berbentuk universitas, institut, maupun sekolah tinggi. ${ }^{1}$

Selanjutnya karena perkembangan ilmu pengetahuan dan kebutuhan untuk mengintegrasikan ilmu di lembaga pendidikan tinggi, integrasi antara ilmu-ilmu yang bersumber dari wahyu dengan ilmu-ilmu yang bersumber dari upaya perolehan manusia, maka sebagian IAIN berubah menjadi Universitas Islam Negeri (UIN), dimulai pada tahun 2002, di saat mana IAIN Syarif Hidayatullah Jakarta berubah menjadi Universitas Islam Negeri Syarif Hidayatullah Jakarta, kemudian diikuti oleh IAIN-IAIN lainnya.

Konversi institut menjadi universitas ini sebenarnya sudah lama dirintis oleh para pendahulu pendiri IAIN. Rencana pengembangan IAIN menjadi UIN kini semakin diintensifkan. IAIN SU juga tidak ketinggalan dalam percaturan perubahan alih status ini. Namun bersamaan dengan itu masih terdapat berbagai kekhawatiran dan permasalahan lainnya yang perlu segera diatasi agar rencana konversi IAIN menjadi UIN itu dapat diwujudkan.

Berdasarkan paparan tersebut di atas, tulisan ini akan mencoba mendeskripsikan hal-hal berikut; Perkembangan Institusional Perguruan Tinggi Islam Indonesia IAIN, STAI, dan UIN, Perbedaan Mendasar antara STAIN, IAIN, dan UIN pada tataran epistemologia dan struktural kelembagaan, Studi Kasus Satu UIN, yaitu UIN SU Medan: Perkembangan (data statistik), Tantangan dan Peluang.

\section{Pembahasan}

\section{Perkembangan Institusional Perguruan Tinggi Islam Indonesia IAIN $\rightarrow$ STAIN $\rightarrow$ UIN}

\section{a. Institut Agama Islam Negeri (1960-1997)}

Institut Agama Islam Negeri (IAIN) diresmikan pada tanggal 24 Agustus 1960 di Yogyakarta. Haidar menyebutkan lembaga ini pada awalnya terlahir dari dua lembaga pendidikan tinggi Islam yang kemudian digabungkan menjadi IAIN.

${ }^{1}$ Haidar Putra Daulay, Pendidikan Islam dalam Sistem Pendidikan Nasional di Indonesia (Jakarta: Kencana Prenada Media Group 2007), cet. ke-3, h. 133. 
Dua lembaga itu adalah Perguruan Tinggi Agama Islam Negeri (PTAIN) yang berada di Yogyakarta dan Akademi Dinas Ilmu Agama (ADIA) yang berada di Jakarta. Tujuan didirikannya IAIN ini adalah untuk memberi pengajaran dan pendidikan universitas serta menjadi pusat dalam mengembangkan dan memperdalam ilmu pengetahuan tentang agama Islam. ${ }^{2}$

IAIN adalah lembaga pendidikan tinggi Islam yang sejak awal kelahirannya telah mengkhususkan diri untuk menjadi lembaga pendidikan tinggi yang mengembangkan ilmu-ilmu keislaman. Dibagilah pengembangan keilmuan di IAIN tersebut kebeberapa fakultas yang kemudian lebih rinci lagi kepada beberapa jurusan. Berdasarkan penetapan Menteri Agama RI Nomor 43 tahun 1960 Jo. Peraturan Menteri Agama No. 15 Tahun 1961 menyatakan bahwa IAIN terdiri atas Fakultas Tarbiyah yang teridiri atas; Jurusan Pendidikan Agama, Jurusan Paedagogis, Jurusan Bahasa Indonesia, Jurusan Bahasa Arab, Jurusan Bahasa Inggris, Jurusan Khusus (lman Tentara), Jurusan Etnologi dan Sosiologi, Jurusan Hukum dan Ekonomi. Fakultas Ushuluddin yang mempuyai 4 jurusan; Jurusan Dakwah, Jurusan Tasawuf, Jurusan Filsafat, dan Jurusan Perbandingan Agama. Fakultas Syariah mempunyai 3 jurusan; Jurusan Tafsir/Hadis, Jurusan Fikih, Jurusan Qadha'. Dan yang terakhir adalah Fakultas Adab, mempunyai 4 jurusan; Jurusan Sastra Arab, Jurusan Sastra Weda, Jurusan Sastra Persia, dan Jurusan Sejarah Kebudayaan Islam. ${ }^{3}$ Pada perkembangan berikutnya jurusanjurusan itu semakin mengecil, ada beberapa jurusan yang hilang, seperti jurusan Bahasa Indonesia, Paedagogik, Iman Tentara, Etnologi dan Sosiologi, Hukum dan Ekonomi, yang tetap bertahan murni pada tahun 1970-an adalah jurusan Pendidikan Agama dan Bahasa Arab.

Dalam perkembangan berikutnya maka bermunculanlah beberapa IAIN di luar Jakarta dan Yogyakarta. Sampai dengan tahun 1973 tercatat ada 14 buah

${ }^{2}$ Haidar Putra Daulay, Sejarah Pertumbuhan dan Pembaruan Pendidikan Islam di Indonesia (Jakarta: Kencana Prenada Media Group 2007), cet. ke-1, h. 122-124.

${ }^{3}$ Ibid., h. 127-128. 
IAIN di seluruh Indonesia. Berikut ini adalah daftar nama-nama 14 IAIN yang ada di Indonesia hingga Tahun 1973: ${ }^{4}$

\begin{tabular}{|c|c|c|c|c|c|c|}
\hline $\begin{array}{l}\mathbf{N} \\
\mathbf{0}\end{array}$ & Nama & Lokasi & $\begin{array}{c}\text { Thn. } \\
\text { Berdiri }\end{array}$ & $\begin{array}{c}\text { Jumlah } \\
\text { Fakultas }\end{array}$ & $\begin{array}{c}\text { Jmlh SP } \\
\text { IAIN }\end{array}$ & $\begin{array}{c}\text { Landasan } \\
\text { Hukum }\end{array}$ \\
\hline 1 & $\begin{array}{l}\text { IAIN Sunan } \\
\text { Kalijaga }\end{array}$ & Yogyakarta & 1960 & 8 & 13 & $\begin{array}{l}\text { Peraturan } \\
\text { Presiden No. } \\
11 / 1960\end{array}$ \\
\hline 2 & $\begin{array}{l}\text { IAIN Syarif } \\
\text { Hidayatullah }\end{array}$ & Jakarta & 1963 & 10 & 6 & $\begin{array}{l}\text { SK Menag No. } \\
49 / 1963\end{array}$ \\
\hline 3 & IAIN Ar-Raniry & Banda Aceh & 1963 & 6 & 12 & $\begin{array}{l}\text { SK Menag No. } \\
89 / 1963\end{array}$ \\
\hline 4 & IAIN Raden Fatah & Palembang & 1964 & 6 & 7 & $\begin{array}{l}\text { SK Menag No. } \\
87 / 1964\end{array}$ \\
\hline 5 & IAIN Antasari & Banjarmasin & 1964 & 9 & 2 & $\begin{array}{l}\text { SK Menag No. } \\
89 / 1964\end{array}$ \\
\hline 6 & $\begin{array}{l}\text { IAIN Sunan } \\
\text { Ampel }\end{array}$ & Surabaya & 1965 & 18 & 18 & $\begin{array}{l}\text { SK Menag No. } \\
20 / 1965\end{array}$ \\
\hline 7 & IAIN Alauddin & $\begin{array}{c}\text { Ujung } \\
\text { Pandang }\end{array}$ & 1965 & 13 & 7 & $\begin{array}{l}\text { SK Menag No. } \\
79 / 1965\end{array}$ \\
\hline 8 & $\begin{array}{l}\text { IAIN Imam } \\
\text { Bonjol }\end{array}$ & Padang & 1966 & 8 & 8 & $\begin{array}{l}\text { SK Menag No. } \\
77 / 1966\end{array}$ \\
\hline 9 & $\begin{array}{l}\text { IAIN Sultan } \\
\text { Thaha Syaifuddin }\end{array}$ & Jambi & 1967 & 4 & 2 & $\begin{array}{l}\text { SK Menag No. } \\
84 / 1967\end{array}$ \\
\hline 10 & $\begin{array}{l}\text { IAIN Sunan } \\
\text { Gunung Jati }\end{array}$ & Bandung & 1968 & 7 & 3 & $\begin{array}{l}\text { SK Menag No. } \\
57 / 1968\end{array}$ \\
\hline 11 & IAIN Raden Intan & $\begin{array}{l}\text { Tanjung } \\
\text { Karang }\end{array}$ & 1968 & 5 & 3 & $\begin{array}{l}\text { SK Menag No. } \\
189 / 1968\end{array}$ \\
\hline 12 & IAIN Walisongo & Semarang & 1970 & 7 & - & $\begin{array}{l}\text { SK Menag No. } \\
31 / 1970\end{array}$ \\
\hline 13 & $\begin{array}{l}\text { IAIN Syarif } \\
\text { Qosim }\end{array}$ & Pekan Baru & 1970 & 3 & 2 & $\begin{array}{l}\text { SK Menag No. } \\
194 / 1970\end{array}$ \\
\hline 14 & $\begin{array}{l}\text { IAIN Sumetara } \\
\text { Utara }\end{array}$ & Medan & 1973 & 4 & 3 & $\begin{array}{l}\text { SK Menag No. } \\
97 / 1973 \text { tgl. } 1 \\
\text { November }\end{array}$ \\
\hline
\end{tabular}

Dalam perkembangan berikutnya IAIN telah berkembang menjadi 5 fakultas, yakni fakultas Tarbiyah, Syariah, Ushuluddin, Adab dan Fakultas Dakwah, dilengkapi dengan berbagai jurusan. Pada tahun 1980-an lahirlah jurusan Tadris, jurusan ini bertujuan untuk menyahuti kekurangan dan kebutuhan guru-

\footnotetext{
${ }^{4}$ Ibid., h. 129.
} 
guru dalam mata pelajaran IPA, Matematika dan Bahasa Inggris. Kemudian pada tahun 1990-an muncul pula jurusan baru yaitu KI (Kependidikan Islam). ${ }^{5}$

\section{b. Sekolah Tinggi Agama Islam (1997- sekarang)}

Berdasaran Keputusan Presiden Nomor 11 Tahun 1997 sejak tanggal 1 Juli 1997 diresmikan 33 Sekolah Tinggi Agama Islam Negeri (STAIN) di seluruh Indonesia. Haidar menyebutkan STAIN berawal dari fakultas-fakultas yang didirikan di daerah oleh IAIN masing-masing. Berdasarkan kebutuhan di berbagai daerah membuka cabang-cabang di luar IAIN induknya sehingga IAIN menjadi berkembang di berbagai daerah, dalam perkembangan itu tidak dapat dihindarkan munculnya duplikasi fakultas. Misalnya ada Fakultas Tarbiyah di IAIN induknya dan ada juga Fakultas Tarbiyah di cabangnya, dan ini bisa terjadi tidak hanya satu fakultas tetapi terdapat beberapa fakultas. Contoh berikutnya sebagaimana disebut juga oleh Haidar, misalnya IAIN Alauddin Ujung Pandang (Makassar) mempunyai fakultas Tarbiyah di IAIN induk yang berpusat di Makassar, dan selain itu IAIN Alauddin memiliki juga beberapa Fakultas Tarbiyah yang berada di luar kota Makassar, misalnya fakultas Tarbiyah di Ambon, Ternate, dan lainlain. Demikian juga dengan fakultas-fakultas lain. Keadaan yang seperti ini ditemukan juga pada IAIN-IAIN lain. ${ }^{6}$

Untuk menghindari duplikasi fakultas, serta untuk menjadikan fakultasfakultas daerah itu mandiri, dan lebih dapat mengembangkan dirinya tidak terikat dengan berbagai peraturan yang agak mengekang oleh IAIN induknya, maka fakultas-fakultas daerah itu dipisahkan dari IAIN induknuya. Setelah dipisahkan lembaga tersebut dinamai STAIN (Sekolah Tinggi Agama Islam Negeri). Misalnya, Fakultas Tarbiyah IAIN Sunan Ampel Malang, berubah menjadi

\footnotetext{
${ }^{5}$ Daulay, Pendidikan Islam..., h. 108.

${ }^{6}$ Haidar Putra Daulay, "Dinamika Pendidikan Tinggi Islam Di Indonesia (Dari Sekolah Tinggi ke Universitas)" dalam Hasan Asari, (ed.), Memperkokoh Eksistensi Memperluas Kontribusi: Antologi Tulisan Para Guru Besar Menyambut UIN SU (Medan: IAIN Press, 2015), cet. ke-1, h. 220-221.
} 
STAIN Malang, atau Fakultas Tarbiyah IAIN Sumatera Utara Padangsidimpuan, kemudian berubah menjadi STAIN Padangsidimpuan, demikian seterusnya. ${ }^{7}$

Sekolah Tinggi Agama Islam Negeri (STAIN) se-Indonesia, berdasarkan keputusan Presiden No. 11 tahun 1997 tanggal 2 Maret 1997 adalah sebagai berikut:

1. STAIN Ambon (sekarang IAIN Ambon)

2. STAIN Batu Sangkar (sekarang IAIN Batu Sangkar)

3. STAIN Bengkulu (sekarang IAIN Bengkulu)

4. STAIN Bukit Tinggi (sekarang IAIN Bukit Tinggi Sumbar)

5. STAIN Cirebon (sekarang IAIN Syekh Nurjati Cirebon Jabar)

6. STAIN Curup

7. STAIN Gorontalo (sekarang IAIN Sultan Amai Gorontalo)

8. STAIN Jember (sekarang IAIN Jember Jatim)

9. STAIN Kediri

10. STAIN Kendari (sekarang IAIN Sultan Qaimuddin Kendari Sulawesi Tenggara)

11. STAIN Kerinci

12. STAIN Kudus

13. STAIN Malang (sekarang UIN Maliki Malang)

14. STAIN Manado (sekarang IAIN Manado)

15. STAIN Mataram (sekarang IAIN Mataram NTB)

16. STAIN Metro

17. STAIN Padang Sidempuan (sekarang IAIN Padang Sidempuan)

18. STAIN Palangkaraya (sekarang IAIN Palangkaraya Kalteng)

19. STAIN Palopo (sekarang IAIN Palopo Sulsel)

20. STAIN Palu (sekarang IAIN Datokarama Palu Sulteng)

21. STAIN Pamekasan

22. STAIN Pare-Pare

23. STAIN Pekalongan

\footnotetext{
${ }^{7}$ Ibid., h. 221.
} 
24. STAIN Ponorogo

25. STAIN Pontianak (sekarang IAIN Pontianak Kalbar)

26. STAIN Purwokerto (sekarang IAIN Purwokerto Jateng)

27. STAIN Salatiga (sekarang IAIN Salatiga Jateng)

28. STAIN Samarinda

29. STAIN Serang (sekarang IAIN Sultan Maulana Hasanuddin Banten)

30. STAIN Surakarta (sekarang IAIN Surakarta)

31. STAIN Ternate (sekarang IAIN Ternate Maluku)

32. STAIN Tulung Agung (sekarang IAIN Tulung Agung Jatim)

33. STAIN Watampone

Selain dari nama-nama tersebut di atas telah muncul pula STAIN baru misalnya, STAIN di Bangka Belitung, STAIN Malikul Shaleh di Lhokseumawe, STAIN Cot Kala di Langsa. Dan ada pula di antara STAIN itu yang telah berubah menjadi IAIN, yaitu STAIN Serang berubah menjadi IAIN Serang, STAIN Mataram berubah menjadi IAIN Mataram, STAIN Gorontalo berubah menjadi IAIN Gorontalo, Sedangkan STAIN Malang berubah menjadi UIN Malang. Dan belakangan menyusul beberapa STAIN ikut berubah menjadi IAIN, seperti STAIN Malikul Shaleh Lhokseumawe berubah menjadi IAIN Malikul Shaleh, STAIN Padang Sidimpuan berubah menjadi IAIN Padang Sidimpuan dan lainnya.

\section{c. Universitas Islam Negeri (2002 - sekarang)}

Dewasa ini lembaga pendidikan tinggi Islam negeri memasuki fase baru, yaitu suatu keadaan ruang lingkup program akademis yang dilaksanakan dalam bentuk institut sudah tidak sesuai lagi dan perlu dikembangkan kepada ruang lingkup program akademis yang lebih luas dalam bentuk universitas. Maka status institut diupayakan berubah menjadi universitas, sehingga menjadi universitas Islam Negeri. IAIN Syarif Hidayatullah Jakarta merupakan IAIN pertama yang berubah menjadi UIN, menjadi UIN Syarif Hidayatullah Jakarta.

Abuddin Nata menjelaskan bahwa ide pengkonversian IAIN menjadi Universitas Islam sebenarnya sudah lama dirintis oleh para pendahulu pendiri 
IAIN. Pemikiran tentang pentingnya lembaga peguruan tinggi Islam yang berbentuk Universitas di Indonesia pernah dirintis sejak zaman Mahmud Yunus. Menurutnya bahwa Universitas Islam Darul Hikmah diresmikan di Bukit Tinggi pada tahun 1957, sebelum menjadi universitas lembaga ini bernama Perguruan Islam Tinggi Darul Hikmah yang berdiri pada tahun $1953 .{ }^{8}$ Kemudian pada periode berikutnya kembali dilontarkan ide tersebut oleh Harun Nasution melihat bahwa IAIN sudah tidak relevan lagi dengan kebutuhan zaman. Telah banyak terjadi perubahan dalam bidang sosial, ekonomi, politik, kebudayaan, ilmu pengetahuan, pola kerja, dan sebagainya. Harun Nasution berpandangan bahwa alumni IAIN di era yang serba modern manuntut sarjana yang menguasai ilmu pengetahuan, teknologi, keterampilan, inovatif, kreatif, progresif, demokratis, ulet, kerja keras, menghargai waktu, visioner, dan dinamis. ${ }^{9}$ Atas tuntutan zaman itulah mulai muncul gagasan perubahan IAIN menjadi universitas, dan berbagai kegiatan seminar, studi banding ke berbagai negarapun dilakukan.

Sejak tahun 2002 telah terjadi perubahan bagi sebagian IAIN menjadi UIN, yaitu IAIN Syarif Hidayatullah Jakarta berdasarkan keputusan Presiden No. 31 Tahun 2002 tanggal 20 Mei 2002. Seterusnya diikuti oleh beberapa IAIN dan satu STAIN. IAIN yang telah berubah ujud menjadi UIN itu adalah IAIN Syarif Hidayatullah menjadi UIN Syarif Hidayatullah. IAIN Sunan Kalijaga Yogyakarta berubah menjadi UIN Sunan Kalijaga Yogyakarta, IAIN Syarif Qasim Pekan Baru berubah menjadi UIN Syarif Qasim Pekan Baru, IAIN Sunan Gunung Jati Bandung berubah menjadi UIN Sunan Gunung Jati Bandung. STAIN Malang berubah menjadi UIN Malang. Belakangan berkembang lagi beberapa IAIN yang berubah menjadi UIN, yaitu UIN Sunan Ampel Surabaya, UIN Ar-Raniry Banda Aceh, UIN Wali Songo Semarang, UIN Raden Fatah Palembang, dan UIN Sumatera Utara Medan. Sehingga pada tahun 2014 jumlahnya sudah mencapai 11 UIN, kesemuanya akan mengembangkan sejumlah ilmu yang tergolong ilmu-ilmu kealaman (natural sciences), ilmu-ilmu sosial (social sciences), humaniora dan

\footnotetext{
${ }^{8}$ Abuddin Nata, Manajeman Pendidikan: Mengatasi Kelemahan Pendidikan Islam di Indonesia (Jakarta: Kencana Prenada Media Group, 2012), cet. ke-5, h. 56.

9 Abuddin Nata, Tokoh-tokoh Pembaruan Pendidikan Islam di Indonesia (Jakarta: Rajawali Pres, 2005), h. 399.
} 
ilmu-ilmu agama. ${ }^{10}$ Sementara itu, pada pertengahan bulan April yang lalu diresmikan kembali enam IAIN berubah menjadi UIN. Keenam UIN yang baru saja alih status itu adalah UIN Mataram, UIN Imam Bonjol Padang, UIN Sultan Thaha Saifuddin Jambi, UIN Raden Intan Lampung, dan UIN Sultan Maulana Hasanuddin Banten. ${ }^{11}$

Dasar perubahan IAIN/STAIN menjadi UIN dengan beberapa pertimbangan:

1) Konsep Pendidikan Islam seutuhnya dan secara khusus konsep Universitas Islam adalah mengembangkan dua jenis keilmuan yaitu perenial khowledge dan acquired knowledge (ilmu naqliyah dan aqliyah) hal ini merupakan hasil Konferensi Pendidikan Islam sedunia).

2) Pada saat dibukanya perkuliahan Sekolah Tinggi Islam (STI) yang pertama tanggal 8 Juli 1945 di Jakarta kurikulum yang dipakai adalah mencontoh kurikulum Fakultas Usuluddin Universitas Al-Azhar Kairo. Erat kaitannya bahwa ketika itu Al-Azhar masih terkonsentrasi kepada ilmu-ilmu diniyah, sedangkan sekarang Al-Azhar telah membuka fakultas-fakultas eksakta, sosial di samping fakultas ilmu-ilmu keagamaan.

3) Sejak diberlakukannya UU. No. 2 tahung 1989 dan UU No. 20 tahun 2003 serta diiringi dengan seperangkat PP, terutama PP No. 28 (tentang Pendidikan Dasar) dan PP No. 29 tahun 1990 (tentang pendidikan menengah), madrasah digolongkan kepada sekolah yang berciri khas agama Islam. Madrasah sebagai sekolah, maka program pokoknya adalah apa yang diberikan di sekolah. Hal ini bermakna tujuan institusional madrasah tidak lagi dipersiapkan untuk mendalami ilmu-ilmu agama. Sehubungan dengan itu maka harus ada lembaga pendidikan tinggi Islam negeri yang akan menampung lulusan madrasah dalam berbagai aspeknya.

\footnotetext{
${ }^{10}$ Daulay, “Dinamika Pendidikan Tinggi Islam Di Indonesia..., h. 230.

${ }^{11} \mathrm{https}$ ://www.kemenag.go.id/berita/490558/kemenag-moratorium-alih-status-iainmenjadi-uin, diakses 20-04-2017.
} 
4) Kecenderungan masyarakat saat sekarang ini adalah menginginkan putra-putri mereka mendalami ilmu-ilmu umum, tetapi memiliki jiwa keagamaan yang kuat.

Sebagai sebuah universitas maka ilmu yang dikembangkan adalah meliputi ilmu kealaman (natural science, sosial social science, humaniora dan ilmu-ilmu keagamaan, yang selanjutnya akan dirancangkan integrasi di antara ilmu-ilmu yang bersumber dari wahyu dengan ilmu yang bersumber dari nonwahyu. ${ }^{12}$

Menurut Haidar Ada beberapa dasar pemikiran yang menjadi landasan perubahan status dari IAIN dan STAIN menjadi UIN, yaitu :

1) Integrasi Ilmu, yaitu mengintegrasikan antara ilmu agama dengan bidang ilmu umum (perenial knowledge dengan accquined knowledge) sehingga antara kedua ilmu itu menjadi menyatu, dan pada akhirnya hilanglah dikotomi dualisme keilmuan.

2) Berubahnya status madrasah sebagai sekolah yang berciri khas agama Islam yang banyak mengkaji ilmu-ilmu umum. Sehingga tamatan Madrasah Aliyah juga dipersiapkan untuk memasuki universitas.

3) Mobilitas dan lapangan kerja yang luas bagi lulusan PTAI. ${ }^{13}$

Senada dengan hal tersebut di atas Ahmad Tafsir menyebutkan lima alasan mengapa IAIN sebaiknya dikembangkan menjadi universitas islami, yaitu:

Pertama, Islam memerlukan pemikir yang mampu berpikir konperhensif. Banyak sekali masalah umat muslim yang tidak dapat diselesaikan secara sempurna dengan hanya menggunakan teori-teori pengetahuan agama seperti selama ini. Masalah-masalah itu baru dapat diselesaikan secara sempurna bila menggunakan juga teori-teori pengetahuan umum. Untuk tujuan ini IAIN harus menjadi UIN. Kedua, ilmu agama memerlukan ilmu umum. Pada saat IAIN dibuka banyak fakultas dan jurusan; semua jurusan itu adalah jurusan yang mendalami ilmu-ilmu agama Islam. Pendalaman ilmu agama Islam pada jurusan

${ }^{12}$ Haidar Putra Daulay, Kapita Selekta Pendidikan Islam di Indonesia (Medan: Perdana Publishing, 2012), h. 48-49.

${ }^{13}$ Daulay, Sejarah Pertumbuhan..., h. 140. 
itu memerlukan bantuan ilmu umum. Jadi, untuk meningkatkan mutu ilmu agama diperlukan bantuan ilmu umum. Kebutuhan itu secara perlahan akan terpenuhi bila IAIN dikembangkan menjadi UIN. Ketiga, meningkatkan harga diri sarjana dan mahasiswa muslim. Masuknya ilmu umum ke IAIN -bila telah menjadi universitas- akan dapat meningkatkan harga diri sarjana dan mahasiswa muslim. Selama ini sarjana dan mahasiswa muslim kurang dikenal di kalangan sarjana dan mahasiswa lainnya. Sebabnya antara lain karena sarjana dan mahasiswa muslim hanya berkiprah dalam ilmu keagamaan, khususnya Islam. Bila IAIN dikembangkan menjadi universitas islami maka lapangan kiprah sarjana dan mahasiswa muslimpun akan lebih luas. Keempat, menghilangkan paham dikotomi agama-umum. Dikotomi antara pengetahuan agama dan pengetahuan umum tidaklah sesuai dengan ajaran Islam. Paham ini harus dihilangkan. Penyatuan kembali pengetahuan agama dan pengetahuan umum dapat dilakukan secara sistemik di universitas islami. Kelima, memenuhi kebutuhan lapangan kerja. Banyak sekali orangtua mahasiswa yang berharap anak-anaknya menjadi sarjana dalam ilmu umum yang memiliki iman yang teguh dan mengetahui juga dasardasar agama Islam. Harapan itu besar kemungkinan dapat dicapai bila anaknya belajar di universitas Islami. ${ }^{14}$

Abuddin Nata juga mengemukakan lima faktor mengapa IAIN menjadi UIN, sebagai berikut: Pertama, adanya perubahan jenis pendidikan pada Madrasah Aliyah yang telah menjadi sekolah umum yang bernuansa agama. Dengan kata lain, muatan matapelajaran umum pada madrasah aliyah sekarang lebih dominan dan lebih kuat dibandingkan muatan matapelajaran agama pada madrasah aliyah di masa sebelumnya; Kedua, adanya dikotomi ilmu-ilmu agama dan ilmu-ilmu umum. Masalah dikotomi tersebut antara lain dapat diatasi dengan program integrasi antara ilmu-ilmu agama dan ilmu-ilmu umum dengan cara mengubah IAIN menjadi UIN; Ketiga, perubahan menjadi UIN akan membuka peluang bagi alumni di lapangan kerja yang lebih luas. Selama ini para lulusan atau sarjana IAIN sebagian besar hanya bekerja di Departemen Agama RI, dan

${ }^{14}$ Ahmad Tafsir, Filsafat Pendidikan Islami: Integrasi, Rohani dan Kalbu Memanusiakan Manusia (Bandung: PT. Remaja Rosdakarya, 2008), cet. ke-3, h. 208-210. 
kalaupun mereka bekerja di departemen atau instansi lainnya, namun bidang pekerjaannya tetap, yaitu bidang agama; Keempat, perubahan menjadi UIN memberi ruang bagi alumni IAIN melakukan mobilitas vertikal, bervariasi dan bergengsi; Kelima, ummat Islam menghendaki adanya pelayanan penyelenggaraan pendidikan yang profesional berkualitas tinggi dan menawarkan banyak pilihan. Hal ini terjadi sebagai akibat dan adanya tuntutan dan era globalisasi yang menghendaki lahirnya manusia-manusia yang unggul dan mampu merebut peluang dalam situasi dan kondisi yang penuh tantangan dan kompetitif. $^{15}$

Dengan perubahan menjadi UIN harapan publik akan pendidikan tinggi Islam yang menjadi pusat dakwak sekaligus lembaga akademi bisa diwujudkan. Selain itu transformasi menjadi UIN akan membuka peluang kerja lebih luas di berbagai departemen. ${ }^{16}$

Namun demikian, upaya melakukan perubahan IAIN menjadi UIN dalam praktiknya bukanlah pekerjaan yang mudah. Di samping adanya kemauan yang keras, kesungguhan, serta kemampuan yang dimiliki oleh para pemimpin dan pengelola IAIN saat ini, juga harus dipertimbangkan tentang kemampuan mengelola, meningkatkan dan mengembangkan secara berkesinambungan.

\section{Perbedaan Mendasar antara STAIN, IAIN dan UIN}

Perguruan Tinggi Islam adalah perguruan tinggi di Indonesia yang pengelolaannya berada di bawah Departemen Agama. Secara teknis akademis, pembinaan Perguruan Tinggi Islam Negeri dilakukan oleh Departemen Pendidikan Nasional sekarang Kemenristek DIKTI, sedangkan secara fungsional dilakukan oleh Departemen Agama sekarang Kemenag. Saat ini Perguruan Tinggi Islam terdiri atas 3 jenis yakni: Universitas Islam Negeri (UIN), Institut Agama Islam Negeri (IAIN), dan Sekolah Tinggi Agama Islam Negeri (STAIN)

${ }^{15}$ Nata, Manajeman Pendidikan..., h. 57-60.

${ }^{16}$ Winarni, Pembaruan Sistem Pendidikan Tinggi Islam di Indonesia: Telaah Konversi IAIN ke UIN, dalam Samsul Nizar (ed.), Sejarah Sosial dan Dinamika Intelektual Pendidikan Islam di Nusantara (Jakarta: Kencana, 2013), h. 352-353. 


\section{a. Sekolah Tinggi Agama Islam Negeri (STAIN)}

Sekolah tinggi merupakan salah satu bentuk perguruan tinggi selain akademi, politeknik, institut, dan universitas. Berdasarkan Undang-Undang Republik Indonesia Nomor 2 Tahun 1989 pasal 16 ayat 2 dan UU Nomor 20 Tahun 2003 pasal 20 ayat 1 tentang Sistem Pendidikan Nasional, sekolah tinggi merupakan salah satu bentuk perguruan tinggi selain akademi, politeknik, institut, dan universitas. Penjelasan pasal 20 ayat 1 UU Nomor 20 Tahun 2003 menyebutkan, "Sekolah tinggi menyelenggarakan pendidikan akademik dan vokasi dalam lingkup satu disiplin ilmu pengetahuan, teknologi, dan seni dan jika memenuhi syarat dapat menyelenggarakan pendidikan profesi". ${ }^{17}$ Sekolah Tinggi memberikan pendidikan dan pengajaran tinggi serta melakukan penelitian dalam satu cabang ilmu pengetahuan.

Sekolah tinggi Islam merupakan perguruan tinggi yang hanya menyelenggarakan pendidikan dalam ruang lingkup Islam, dan hanya mempunyai satu fakultas dan terbagi kedalam berbagai jurusan. Berikut adalah Sebagian daftar STAIN di Indonesia :

STAIN Gajah Putih, Takengon

STAIN Jember, Jember

STAIN Kediri, Kediri

STAIN Kudus, Kudus

\section{b. Institut Agama Islam Negeri (IAIN)}

Institut adalah perguruan tinggi yang menyelenggarakan pendidikan akademik dan vokasi dalam sekelompok disiplin ilmu pengetahuan, teknologi, serta seni dan jika memenuhi syarat dapat menyelenggarakan pendidikan profesi. Institut, memberikan pendidikan dan pengajaran tinggi serta melakukan penelitian dalam beberapa cabang ilmu pengetahuan sejenis.

${ }^{17}$ Undang-undang RI No. 20 Tahun 2003, tentang Pendidikan Nasional, Departemen Agama RI, 2005. 
Institut merupakan perguruan tinggi yang terdiri atas sejumlah fakultas yang menyelenggarakan pendidikan akademik dalam sekelompok disiplin ilmu yang sejenis. (Pasal 16 Angka 6 UU Nomor 2 Tahun 1989 Tentang Sistem Pendidikan Nasional).

Institut agama Islam merupakan pendidikan tinggi Islam yang terdiri dari sejumlah fakultas dan menyelenggarakan pendidikan yang di kaitkan dengan agama islam, seperti, hukum/syari'at Islam, perbandingan agama, pendidikan agama. Salah satu contohnya yaitu: IAIN Cirebon Jawa Barat, IAIN Padangsidimpuan SUMUT dan lainnya.

\section{c. Universitas Islam Negeri (UIN)}

Universitas adalah suatu institusi pendidikan tinggi dan penelitian, yang memberikan gelar akademik dalam berbagai bidang. Sebuah universitas menyediakan pendidikan sarjana dan pascasarjana. Kata universitas berasal dari bahasa Latin universitas magistrorum et scholarium, yang berarti "komunitas guru dan akademisi".

Universitas Islam yaitu pendidikan tinggi islam yang mempunyai banyak rumpun ilmu, pengelolaannya berada di bawah Kementerian Agama. Secara teknis akademik, pembinaan perguruan tinggi Islam negeri dilakukan oleh Kementerian Pendidikan dan Kebudayaan, sedangkan secara fungsional dilakukan oleh Kementerian Agama.

Institusi seperti universitas ini telah ada di Persia dalam dunia Islam, salah satu yang terkenal adalah Akademi Gundisapur dan juga Universitas Al Azhar di Kairo, yang merupakan universitas tertua di dunia yang masih beroperasi. Salah satu universitas di Asia yang terkenal lainnya adalah Universitas Nalanda di Bihar, India, di mana filsuf Buddha abad ke-2 Nagarjuna berpusat. ${ }^{18}$

Universitas dalam pendidikan di Indonesia merupakan salah satu bentuk perguruan tinggi selain akademi, institut, politeknik, dan sekolah tinggi.

\footnotetext{
${ }^{18}$ https://mirsadimurdan1996.blogspot.co.id/2016/pengertian-persamaan-danperbedaan.html, diakses 12 April 2017
} 
Universitas terdiri atas sejumlah fakultas yang menyelenggarakan pendidikan akademik dan pendidikan vokasi dalam sejumlah ilmu pengetahuan, teknologi, dan/atau seni dan jika memenuhi syarat dapat menyelenggarakan pendidikan profesi.

Universitas tersusun atas dasar keseluruhan, kesatuan ilmu pengetahuan dan terbagi atas sekurang-kurangnya 4 golongan Fakultas yang meliputi Ilmu Agama/Kerohanian, Ilmu Kebudayaan, Ilmu Sosial, Ilmu Eksakta dan Teknik, dan sebagainya.

Berdasarkan uraian di atas dapat disimpulkan bahwa Sekolah Tinggi yaitu pendidikan tinggi yang memberikan pendidikan serta melakukan penelitian dalam satu cabang ilmu pengetahuan, dan terdiri dari satu fakultas yang terbagi ke dalam berbagai jurusan. Institut adalah Perguruan Tinggi yang tersusun atas dasar keseluruhan ilmu pengetahuan dan teknologi sejenis. Dan Mempunyai beberapa rumpun ilmu dan fakultas, serta bidang nya lebih sempit dari pada universitas. Sedangkan Universitas Pendidikan tinggi yang menyelenggarakan pendidikan dalam cabang ilmu yang lebih luas, yang tersusun atas dasar keseluruhan, kesatuan ilmu pengetahuan dan terbagi atas sekurang-kurangnya 4 golongan Fakultas.

\section{Universitas Islam Negeri Sumatera Utara (UIN SU): Perkembangan (data statistik), Tantangan dan Peluang.}

UIN Sumatera Utara dahulunya IAIN Sumatera Utara didirikan pada tanggal 19 November 1973 memiliki sejarah yang panjang. Berdirinya dilatar belakangi dan didukung oleh beberapa faktor pertimbangan objektif. Pertama, Perguruan Tinggi Islam yang berstatus Negeri pada saat itu belum ada di Provinsi Sumatera Utara, walaupun yang berstatus swasta memang sudah ada. Kedua, pertumbuhan pesantren, madrasah dan perguruan-perguruan agama yang sederajat dengan SLTA di daerah Sumatera Utara tumbuh dan berkembang dengan pesatnya, yang sudah tentu memerlukan adanya pendidikan lanjutan yang sesuai, yakni adanya perguruan Tinggi Agama Islam yang berstatus Negeri. 
Dalam suasana yang demikian, timbullah inisiatif $\mathrm{H}$. Ibrahim Abdul Halim, kepala inspeksi Pendidikan Agama Provinsi Sumatera Utara, beserta teman-temannya untuk mendirikan Fakultas Tarbiyah di Medan. Usaha ini terwujud dengan terbentuknya suatu Panitia Pendirian Fakultas Tarbiyah Persiapan IAIN pada tanggal 24 Oktober 1960, yang diketuai oleh Letkol. Raja Syahnan.

Seiring dengan berdirinya Fakultas Tarbiyah Persiapan IAIN Medan, Yayasan K.H. Zainul Arifin pada tahun 1967 mendirikan Fakultas Syari'ah, yang juga ingin berubah menjadi berstatus negeri, sebagaimana halnya dengan Fakultas Tarbiyah IAIN Medan. Yaitu dengan mengajukan surat permohonan Nomor 199/YY/68 tanggal 20 Juni 1968 kepada Menteri Agama RI di Jakarta. Untuk mewujudkan keinginan itu, Menteri Agama mengambil mengambil kebijaksanaan dengan menggabungkan Panitia Penegerian Fakultas Tarbiyah dengan Panitia Penegerian Fakultas Syari'ah. Akhirnya, penegerian kedua fakultas serentak dilakukan pada hari Sabtu tanggal 12 Oktober 1968 bertepatan dengan tanggal 20 Rajab 1389 H, oleh Menteri Agama RI K.H. Moh. Dahlan, bertempat di Aula Fakultas Hukum USU Medan.

Walaupun sejak tanggal 12 Oktober 1968 Menteri Agama RI telah meresmikan 2 (dua) buah Fakultas yang berkedudukan di Medan sebagai Fakultas Cabang dari IAIN Ar-Raniry Banda Aceh, namun semangat dan tekad untuk mewujudkan IAIN yang berdiri sendiri di Medan tetap menjadi harapan setiap warga masyarakat. Respons dari pihak Pemerintah Daerah dan Departemen Agama RI untuk memenuhi keinginan agar suatu waktu IAIN penuh dan berdiri sendiri terwujud di Medan, ditindaklanjuti dengan mempersiapkan gedunggedung perkuliahan perpustakaan, tenaga dosen dan administrasi serta sarana dan prasarana pendidikan lainnya.

Demikianlan pada hari Senin, 24 Syawal 1393 H, bertepatan dengan tanggal 19 Nopember 1973, pukul 10.00 Wib, IAIN Sumatera Utara resmi berdiri yang ditandai dengan pembacaan Piagam Pendirian oleh Menteri Agama RI Prof. Dr. H. Mukti Ali, M.A. sejak saat itu, resmilah Fakultas Tarbiyah dan Fakultas 
Syari'ah IAIN Ar-Raniry yang ada di Medan serta Fakultas Tarbiyah dan Fakultas Ushuluddin IAIN Imam Bonjol yang ada di Padangsidimpuan menjadi IAIN Sumatera Utara sesuai dengan keputusan Menteri Agama RI Nomor 97 Tahun 1973, tanggal 19 Nopember $1973 .^{19}$

Dalam konteks sejarah IAIN di Indonesia, IAIN SU yang berdiri pada tanggal 19 November 1973 merupakan IAIN termuda. Kendatipun saat ini status termuda itu tak lagi bisa disandangnya. Karena memang sudah banyak IAIN dan juga STAIN yang dilahirkan Kemenag sebagai pertanda bahwa PTKIN semakin diminati masyarakat Indonesia. Jika tanggal 16 Oktober 2014 adalah hari yang spesial bagi IAIN SU, karena diterbitkannya Peraturan Presiden Nomor 131 Tahun 2014 tentang ketetapan pendirian Universitas Islam Negeri Sumatera Utara Medan, berarti perlu waktu 41 tahun bagi IAIN SU untuk menjadi perguruan tinggi yang sebenarnya. Sebagaimana diketahui, sepanjang status PTKIN masih Institut, lembaga ini hanya berhak mengelola satu bidang ilmu saja yaitu ilmu agama. Berbeda jika statusnya Universitas yang boleh mengelola seluruh bidang ilmu, ilmu agama, ilmu alam, ilmu sosial juga ilmu terapan. ${ }^{20}$

Transformasi perguruan tinggi Islam mencakup banyak aspek, baik institusional, struktural maupun kultural dan sosial. Perubahan bentuk dari STAIN menjadi IAIN, atau IAIN menjadi UIN adalah transformasi dalam arti institusional. Beberapa perguruan tinggi Islam yang dulunya masih berstatus IAIN dan sekarang beralih status menjadi Universitas Islam Negeri (UIN), menunjukkan kemajuan yang sangat pesat. UIN Syarif Hidayatullah Jakarta dikenal sebagai jendela Islam Indonesia di mata internasional dan menjadi world class university. UIN Sunan Kalijaga Yogyakarta membangun Center of Excelence ilmu-ilmu keislaman. UIN Maulana Malik Ibrahim Malang mengembangkan perpaduan antara sistem pesantren ( $M a$ 'had) dan kampus untuk melahirkan calon ilmuwan dan ulama'. UIN Sunan Ampel Surabaya dengan paradigma Integrated Twin Towers membangun keilmuan integratif

\footnotetext{
${ }^{19}$ Buku Panduan Akademik IAIN Sumatera Utara Tahun Akademik 2009/2010, h. 19-20.

${ }^{20}$ Azhari Akmal Tarigan, Don'n Be Chicken: Biografi Intelektual Prof. Dr. Nur A. Fadhil Lubis, MA (Medan: Perdana Publishing, 2017), cet. ke-1, h. 187.
} 
multidisipliner, mewujudkan Islam transformatif. ${ }^{21}$ Sedangkan UIN SU Medan mengusung sistem integrasi keilmuan sehingga membentuk ilmu baru dengan metode yang baru yang dikenal dengan istilah trandisipliner. ${ }^{22}$

Menurut Fadhil (eksekutor alih status IAIN SU menjadi UIN SU), perubahan IAIN SU menjadi UIN SU itu bermakna kepada beberapa hal pokok, yaitu:

Pertama, alih status itu berarti pergeseran paradigma keilmuan IAIN SU dari mono disiplin menjadi trandisiplin. Kedua, pergeseran fokus keilmuan dari ulum al-diniyah menjadi Ilmu Pengetahuan, Tekhnologi dan Seni. Ketiga, transformasi IAIN SU menjadi UIN SU juga mengandung arti pergeseran fokus pengabdian UIN SU dari umat sentries menjadi rahmatan li al-'alamin. Keempat, transformasi itu juga bermakna tujuan pendidikan di UIN SU. Jika dahulu masih menjadi IAIN SU, lembaga ini diharapkan melahirkan ulama-ulama yang kompeten dalam keilmuan dan terjaga integritasnya, setelah menjadi UIN SU, fokus tidak lagi melahirkan ulama dalam maknanya yang sempit. Tujuan kita adalah melahirkan ulul al-bab, satu konsep yang ditawarkan Alquran. Fadhil ingin melihat bahwa bukan saja IAIN yang berubah menjadi UIN SU. Tetapi juga terdapat perubahan budaya, cara kerja, sistem berpikir, dan moralitas yang akan menjadikan UIN SU benar-benar UIN SU. Bukan UIN yang basa basi. Tidak juga UIN yang rasanya masih IAIN. ${ }^{23}$

Dalam usianya terbilang muda, belum genap tiga tahun, UIN SU diberi amanah membuka tiga fakultas baru yakni Fakultas Ilmu Sosial, Fakultas Sains dan Teknologi, serta Fakultas Kesehatan Masyarakat. Ketiga fakultas ini menunjukkan kepercayaan pemerintah dan masyarakat kepada lembaga ini meningkat secara signifikan. Pada saat ini Fakultas Ilmu Sosial memiliki dua program studi yaitu; Ilmu Komunikasi dan Ilmu Perpustakaan. Sementara itu Fakultas Sainstek memiliki 5 program studi yaitu; Matematika, Biologi, Fisika,

\footnotetext{
${ }^{21}$ http://diktis.kemenag.go.id/artikel, diakses 19 Februari 2017.

${ }^{22}$ Tarigan, Don'n Be Chicken..., h. 192.

${ }^{23}$ Ibid., h.192-194.
} 
Ilmu Komputer, dan Sistem Informasi. Sedangkan Fakultas Kesehatan Masyarakat memiliki satu program studi yaitu Ilmu Kesehatan Masyarakat. ${ }^{24}$

Perkembangan lainnya yang juga dirasakan signifikan adalah meningkatnya jumlah mahasiswa yang sebelumnya ketika berstatus IAIN berjumlah tidak lebih dari 8000 orang, berdasarkan data Oktober tahun 2015 UIN SU memiliki total mahasiswa 12.806 orang, yang tersebar pada program Diploma III 563 orang, Program Sarjana 10.466 orang. Program Magister 1.277 orang dan Program Doktor 460 orang.

Sejalan dengan bertambahnya jumlah mahasiswa maka secara otomatis bertambah pula jumlah Tenaga Pendidik, tercatat pada tahun yang sama, UIN Sumatera Utara adalah rumah bagi 399 orang dosen tetap yang memiliki berbagai bidang keahlian. Dari jumlah tersebut sebanyak 28 orang adalah para guru besar. Dari segi kualifikasi akademik, sejumlah 68 orang berpendidikan doktor (S3) dan 328 orang berpendidikan Magister (S2). Di samping dosen tetap UIN SU juga didukung oleh 300 orang lebih dosen tidak tetap. Berikut ini daftar nama-nama guru besar UIN SU dan bidang keahliannya:

\begin{tabular}{c|l|l}
\multicolumn{1}{c}{ No } & \multicolumn{1}{c}{ Nama } & \multicolumn{1}{c}{ Bidang Keahlian } \\
\hline $\mathbf{1}$ & Prof. Dr. A. Ya'kub Matondang, MA & Tafsir \\
\hline $\mathbf{2}$ & Prof. Dr. Mo. Hatta & Ilmu Dakwah \\
\hline $\mathbf{3}$ & Prof. Dr. Ilhamuddin, MA & Ilmu Kalam \\
\hline $\mathbf{4}$ & Prof. Dr. Asmuni, M.Ag & Fikih \\
\hline $\mathbf{5}$ & Prof. Dr. Syukur Kholil, MA & Komunikasi \\
\hline $\mathbf{6}$ & Prof. Dr. Lahmuddin, M.Ed & Bimbingan Konseling \\
\hline $\mathbf{7}$ & Prof. Dr. M. Yasir Nasution & Filsafat Hukum Islam \\
\hline $\mathbf{8}$ & Prof. Dr. Amiur Nuruddin, MA & Ekonomi Islam \\
\hline $\mathbf{9}$ & Prof. Dr. Haidar Putra Daulay, MA & Sejarah Pendidikan Islam \\
\hline $\mathbf{1 0}$ & Prof. Dr. Abbas Pulungan & Sejarah Peradaban Islam \\
\hline $\mathbf{1 1}$ & Prof. Dr. Dja'far Siddik, MA & Ilmu Pendidikan Islam \\
\hline
\end{tabular}

${ }^{24}$ Buku Profil Universitas Islam Negeri Sumatera Utara tahun 2015, h. 20. 


\begin{tabular}{|c|c|c|}
\hline 12 & Prof. Dr. Saiful Akhyar Lubis, MA & Bimbingan Konseling Islam \\
\hline 13 & Prof. Dr. Fachruddin, MA & Administrasi Pendidikan \\
\hline 14 & Prof. Dr. Abd. Mukti, MA & Sejarah Pendidikan Islam \\
\hline 15 & Prof. Dr. Syafaruddin, M.Pd & Manajemen Pendidikan \\
\hline 16 & Prof. Dr. Hasan Asari, MA & Sejarah Pendidikan Islam \\
\hline 17 & Prof. Dr. Nur A. Fadhil Lubis, MA & Filsafat Ilmu \\
\hline 18 & Prof. Dr. Ahmad Qorib, MA & Ushul Fikih \\
\hline 19 & Prof. Dr. Nawir Yuslem, MA & Ilmu Hadis \\
\hline 20 & Prof. Dr. Pagar, MA & Peradilan Islam \\
\hline 21 & Prof. Dr. Syahrin Harahap, MA & Islam Modern \\
\hline 22 & Prof. Dr. Hasyimsyah Nasution, MA & Pemikiran Islam \\
\hline 23 & Prof. Dr. Ramli A. Wahid & Hadis \\
\hline 24 & Prof. Dr. Hasan Bakti Nasution, M.Ag & Metode Studi Islam \\
\hline 25 & Prof. Dr. Amroeni Drajat, M.Ag & Filsafat Islam \\
\hline 26 & Prof. Dr. Katimin, M.Ag & Sejarah Politik Islam \\
\hline 27 & Prof. Dr. Abdullah, M.Si & Filsafat Dakwah \\
\hline 28 & Prof. Dr. Al Rasyidin, M.Ag & Filsafat Pendidikan Islam \\
\hline 29 & Prof. Dr. Sidurrahman, M.Ag & Politik Islam \\
\hline 30 & Prof. Dr. Sukiman, M.Si & Pemikiran Islam \\
\hline 31 & Prof. Dr. Muzakkir, MA & Tasawuf \\
\hline
\end{tabular}

Selain hal tersebut di atas, setelah beralih status IAIN ke UIN, dapat dirasakan juga adanya penambahan SDM di bidang administrasi, tenaga administrasi yang bertugas di UIN SU seluruhnya berjumlah 151 orang, 42 di antaranya menduduki jabatan struktural pada eselon, II, III dan IV, 10 orang dengan jabatan fungsional pustakawan, 5 orang fungsional arsiparis, 4 orang pranata komputer, 1 orang peneliti dan 1 orang fungsional perencana. ${ }^{25}$

Dan satu hal yang tak kalah pentingnya adalah jaringan kerjasama dalam dan luar negeri. Sebagai sebuah lembaga milik pemerintah, UIN SU menjadi

\footnotetext{
${ }^{25}$ Ibid., h. $10-12$.
} 
bagian dari sebuah jaringan lembaga Pendidikan Tinggi Keagamaan Islam Negeri (PTKIN) yang berjumlah 55 dan tersebar di seantero Indonesia. Di samping itu, untuk lebih meningkatkan pelayanannya, UIN SU membangun jaringan dan melakukan kerja sama dengan berbagai lembaga, baik di dalam maupun di luar negeri. Peningkatan status menjadi sebuah universitas dengan sendirinya menuntut UIN SU untuk lebih banyak bekerja sama dengan universitas terkemuka demi mengakselerasi perkembangannya ke masa depan. Berikut ini sejumlah nama-nama lembaga kerjasama luar negeri:

1) Akademi Pengajian Dakwah, Kedah Malaysia

2) Goverment of India

3) Hamdard University India

4) Colombo Plan Staff Collage for Technician Education

5) Jamiyah Singapore

6) Kolej Islam Pahang Sultan Ahmad Shah (KIPSAS)

7) Kolej Islam Teknologi Antar Bangsa (KITAB)

8) Kolej Islam Sains dan Teknologi (KIST)

9) Kolej Universiti Darul Quran Ismiyah

10) Marmara University, Istambul Turkey

11) Sistem Pendidikan Pahang Sdn Bhd

12) The United State of America

13) Universiti Kebangsaan Malaysia

14) University of Fune, India

15) Yala Islamic Collage Thailand

16) Yarmouk University Jordan

Kerjasama dalam negeri:

1) Asuransi Bumi Putra

2) Badan Pendidikan dan Latihan Provsu

3) Bank Indonesia

4) Bank Syariah Mandiri

5) Pemkab Serdang Bedagai 
6) Dinas Pendidikan Provsu

7) Kanwil Dep. Kum \& Ham

8) Pemkab. Asahan

9) Pengadilan Tinggi Agama Medan

10) Persatuan Wartawan Indonesia

11) PT. Multi Dinamika Consultant Indonesia

12) STAIN Padang Sidempuan

13) Universitas Pembangunan Panca Budi (UNPAB)

14) $\mathrm{BPDAS}^{26}$

Selanjutnya, tulisan ini juga menyoroti peluang dan tantangan peralihan status IAIN SU menjadi UIN SU, di antara konsekuensi peralihan status ini adalah terjadinya perubahan diberbagai lini, termasuk dalam penyelenggaraan pendidikan dari semula yang berbasis keilmuan agama Islam saja menjadi lebih luas melalui pola ekspansi dan integrasi keilmuan. Ilhamuddin berpendapat, peralihan UIN SU merupakan momen penting yang memberikan peluang bagi perguruan tinggi ini untuk berkembang lebih baik. Tentu saja peralihan menjadi UIN tak dapat tidak juga mendorong bagi terjadinya berbagai perubahan di berbagai bidang, baik administrasi, keuangan, akademik maupun hubungan kerjasama nasional dan internasional. $^{27}$

Lebih lanjut Ilhamuddin menjelaskan, bagi UIN SU Medan yang masih berusia muda sekarang ini tentu pencarian bentuk adalah sesuatu yang tidak terelakkan. Menurutnya integrasi keilmuan bukanlah perkara mudah. Hal ini melibatkan banyak hal, terutama sumberdaya manusianya. Para dosen di UIN SU ini adalah warisan IAIN SU yang keterampilannya tentu sesuai dengan kebutuhan pada masa IAIN SU sebelumnya. Menghadirkan tenaga dosen baru dengan keilmuan yang sudah terintegrasi antara keilmuan Islam dan keilmuan umum juga tidak mudah, karena hal ini membutuhkan proses. Bahkan dapat dikatakan belum

\footnotetext{
${ }^{26}$ Ibid., h. 26.

${ }^{27}$ Ilhamuddin, "Prospek dan Potensi Konribusi Perubahan IAIN SU Medan Menjadi UIN SU Medan Bagi Peradaban: Perspektif Ilmu Kalam" dalam Hasan Asari, (ed.), Memperkokoh Eksistensi Memperluas Kontribusi: Antologi Tulisan Para Guru Besar Menyambut UIN SU (Medan: IAIN Press, 2015), cet. ke-1, h. 130.
} 
ada produk perguruan tinggi di dunia ini yang telah secara massif melahirkan sarjana dengan keilmuan integratif sebagaimana dimaksud. Alhasil, haruslah ada proses untuk menunggu lahirnya alumni dengan keilmuan yang integratif seperti yang diharapkan. Boleh jadi dari alumni sendiri atau dari alumni perguruan tinggi lain. $^{28}$

Hasyimsyah Nasution menilai dengan berubahnya IAIN SU menjadi UIN SU membawa implikasi diberinya kewenangan kepada lembaga ini selain menyelenggarakan program pendidikan tinggi ilmu agama Islam, juga dapat menyelenggarakan program pendidikan tinggi ilmu lain. Hal ini berarti UIN SU ke depan memiliki peranan besar dalam pengembangan keilmuan, teknologi, dan seni sebagai halnya sifat universitas. Ia menambahkan, tentu saja hal itu, selain sebagai peluang sekaligus menjadi tantangan mengingat usianya yang masih relatif muda dan baru lahir yang menuntut pembenahan dalam banyak hal, diantaranya: hal terkait dengan pengelolaan lembaga, pembenahan infra struktur, fasilitas pendukung akademis, dan kualitas tenaga kependidikan, serta komitmen seluruh insan kampus untuk bermental siap maju melalui kerja keras secara bersama-sama yang terencana dengan baik. ${ }^{29}$

Menurut pantauan penulis, ada sejumlah tantangan sekaligus persoalan yang dihadapi UIN SU dan dihadapi pula oleh mayoritas perguruan tinggi lainnya, yaitu: Pertama, politik kampus. Keadaan ini biasanya terlihat jelas ketika pemilihan Rektor dan Wakil Rektor baru, dimana Rektor terpilih akan menonaktifkan rivalnya dari jabatan sebelumya bila ia menduduki suatu jabatan, selanjutnya menggantinya dengan koleganya, seperti timsesnya maupun sanak saudaranya. Bila mana Rektor terpilih dari suku tertentu atau bermarga tertentu, maka ia akan mengangkat saudara satu sukunya atau semarganya dan seterusnya. Hal ini bisa menghambat laju pengembangan UIN SU bila yang menduduki suatu jabatan tidak profesional. Kedua, komitmen pegawai yang rendah untuk

\footnotetext{
${ }^{28}$ Ibid.

${ }^{29}$ Hasyimsyah Nasution, "Perkembangan Pemikiran dalam Islam: Kiprah UIN SU dalam Upaya Pemberdayaan Nilai" dalam Hasan Asari, (ed.), Memperkokoh Eksistensi Memperluas Kontribusi: Antologi Tulisan Para Guru Besar Menyambut UIN SU (Medan: IAIN Press, 2015), cet. ke-1, h. 124.
} 
memajukan lembaga. Ini juga merupakan tantangan berat bagi pemangku kebijakan untuk merubahnya, sebab mereka mengira institusi ini adalah milik pemerintah bila tidak ada seorangpun yang berkomitmen untuk memajukannya niscaya pemerintah akan bertanggungjawab untuk mencarikan solusi dari persoalan itu. Dan yang lebih mirisnya mereka malah berkiprah pada institusi lain di luar kampusnya baik di sekolah-sekolah maupun madrasah-madrasah yang mereka kelola sendiri ataupun bersinergi dengan orang lain. Ketiga, rendahnya tradisi disiplin. Persoalan ini ditandai dengan datang tidak tepat waktu alias terlambat dan pulang dari tempat kerja lebih awal. Keempat, menghabiskan anggaran di akhir tahun. Sudah menjadi tradisi yang cukup mengakar bahwa di akhir tahun khususnya lembaga perguruan tinggi negeri mempunyai hajat yang cukup padat guna melakukan penghabisan anggaran di tahun yang sedang berjalan. Akibatnya banyak kegiatan yang menumpuk untuk dilaksanakan namun kurang efektif dan tidak tepat sasaran. Kelima, persoalan meningkatkan nilai akreditasi prodi dan institusi. Mendapatkan nilai akreditasi maksimal adalah citacita setiap pimpinan prodi dan institusi, namun perkara ini sulit dicapai disebabkan prodi-prodi yang ada terus bertambah seiring berubahnya status IAIN menjadi UIN. Bila suatu prodi belum mengeluarkan alumni maka sulit untuk mendapatkan nilai akreditasi maksimal (nilai B atau A), demikian halnya dengan nilai akreditasi institusi.

Perkembangan UIN saat ini bukanlah tanpa kritik, termasuk UIN SU Medan. M. Atho Mudzhar mengkritik bahwa transformasi UIN belum menampakkan hasil yang memuaskan, karena belum menyerap ke dalam perubahan metodologi studi Islam. Program studi yang ada di UIN saat ini masih baru tahap masuknya program studi eksakta, konsep integrasinya tidak jelas. Selain itu pada Program Pascasarjana di UIN masih berkutat pada program studi kajian keislaman, demikian pula dengan topik tesis dan disertasi yang diangkat, tidak ada bedanya ketika masih IAIN. Hingga saat ini di UIN belum ada Program Pascasarjananya yang memiliki program unggulan selain kajian Islam. Akan tetapi menurut Hasan Asari kritikan itu semua akan terjawab semua seiring berjalannya waktu, maksudnya adalah bahwa semua persoalan yang disebutkan 
diatas akan ditemukan solusinya dan satu persatu akan sirna. Biarlah waktu yang berbicara tukasnya.

Perubahan IAIN menjadi universitas, bukanlah tanpa masalah. Abuddin Nata menjelaskan, di dalamnya terdapat sejumlah permasalahan baik yang bersifat kelembagaan, filosofis, historis, psikologis, dan bahkan politis. Dari segi kelembagaan, ada satu pertanyaan penting Yaitu, apakah setelah IAIN berubah menjadi universitas nantinya tetap berada di bawah naugan Depag (sekarang Kemenag), atau berada di bawah Depdiknas (sekarang Kemenristek Dikti). Jika IAIN yang sudah berubah menjadi UIN tetap berada di bawah anungan Kemenag akan mengalami kesulitan dalam hal tersedianya organ untuk membina fakultasfakultas umum. Organ untuk membina fakultas-fakultas umum ini berada pada Kemenristek Dikti. Demikian juga bila IAIN yang sudah berubah menjadi UIN ini berada di bawah naungan Kemenristek Dikti juga akan mengalami kesulitan, karena lembaga ini tidak cukup tersedia unit yang membina fakultas-fakultas agama yang ada di UIN. Untuk mengatasi masalah ini Nata menyebutkan, pembina UIN tetap Kemenag, sedangkan untuk fakultas-fakultas umum berada di bawah pembinaan Kemenristek Dikti. Ia mengusulkan pengaturan wewenang UIN oleh dua kementrian ini perlu dituangkan dalam aturan surat keputusan bersama antara Kemenristek Dikti dan Kemenag. ${ }^{30}$

Persoalan selanjutnya berkaitan dengan latar belakang filosofis-historis. Secara filosofis, keberadaan IAIN merupakan lembaga yang dengan khusus mengkaji, mendalami, dan mengembangkan ajaran Islam. Secara historis, kehadiran IAIN merupakan perjuangan dakwah Islam yang dilakukan oleh para tokoh muslim. Hasil perjuagan ini dinilai begitu berharga dan tercatat dalam sejarah umat Islam Indonesia. Dan sangat disayangkan manakala perjuangan ini dihapus dan dibuang begitu saja. Untuk mengatasi permasalahan ini Nata mengusulkan tetap mempertahankan, bahkan mengembangkan fakultas-fakultas agama yang ada saat ini, dan bukan malah menghilangkan atau menciutkannya. Jika pertimbangan ini diperhatikan, maka kekhawatiran sebagian kalangan

\footnotetext{
${ }^{30}$ Nata, Manajeman Pendidikan..., h. 63.
} 
terhadap hilangnya atau menciutnya fakultas-fakultas agama yang ada di IAIN dengan berubahnya menjadi UIN, dapat diatasi. ${ }^{31}$

Masalah berikutnya yang muncul berkaitan dengan perubahan IAIN menjadi UIN ini berkenaan dengan pertimbangan yang bersifat politis. Menurut sejarah, bahwa berdirinya IAIN merupakan anugerah dan penghargaan dari pemerintah saat itu terhadap peran dan kontribusi umat Islam dalam memperjuangkan kemerdekaan Republik Indonesia. Berdasarkan hal itu, umat Islam diberi tempat dan kesempatan untuk memasyarakatkan dan mengembangkan ajaran Islam, melalui lembaga IAIN inilah proses peningkatan dan pemberdayaan kualitas sumber daya manusia dapat dilakukan. Perubahan IAIN menjadi UIN ini dikhawatirkan bisa mengubur fakta historis politis umat Islam tersebut. Namun kekhawatiran ini dapat diatasi dengan perubahan IAIN menjadi UIN ini justru akan melahirkan para sarjana muslim yang berkualitas unggul yang pada gilirannya dapat melakukan peran sosial politik dan sebagainya di Republik ini. Sebaliknya, jika IAIN tetap dibiarkan seperti sekarang, maka IAIN hanya akan menghasilkan para sarjana yang ruang geraknya amat terbatas, kurang mampu bersaing pada era global yang kompetitif, dan pada akhirnya akan terpinggirkan. $^{32}$

Meskipun dengan berbagai persoalan demikian, perubahan IAIN SU ke UIN SU sepatutnya dipahami sebagai anugerah yang harus disyukuri, betapa tidak arus perubahan di lingkungan PTKIN (Perguruan Tinggi Keagamaan Islam Negeri) belakangan ini sangatlah derasnya dan jika perubahan status yang sudah dimiliki ini dapat dikelola dengan baik sangatlah bermanfaat bagi generasi muda ke depan.

\section{Kesimpulan}

Selama tujuh puluh tahun lebih, sejak tahun 1945 sampai tahun 2017, telah terjadi dinamika perguruan tinggi Islam di Indonesia, dinamika itu dapat dibagi kepada tiga fase perkembangan, yaitu: pertama, berbentuk sekolah tinggi,

\footnotetext{
${ }^{31}$ Ibid.

${ }^{32}$ Ibid., h. 65 -66.
} 
termasuk didalamnya jenis pendidikan tinggi: Sekolah Tinggi Islam (STI), Perguruan Tinggi Agama Islam Negeri (PTAIN), Akademi Dinas Ilmu Agama (ADIA) dan terakhir Sekolah Tinggi Agama Islam Negeri (STAIN). Pada fase ini kelompok keilmuan dikembangkan satu disiplin ilmu keislaman. Kelompok kedua, adalah bentuk institut, di sini pengembangan keilmuannya lebih meluas dari kelompok pertama, lembaga inilah yang bernama Institut Agama Islam Negeri (IAIN), di lembaga ini dikembangkan sekelompok ilmu sejenis yang dalam hal ini ilmu-ilmu keagamaan Islam. Ketiga, adalah berbentuk universitas, pada lembaga ini akan dikembangkan sejumlah disiplin ilmu yang mencakup: ilmu-ilmu kealaman, ilmu-ilmu sosial, humaniora, dan ilmu-ilmu keagamaan.

Kehadiran Universitas Islam Negeri Sumatera Utara (UIN SU) akan bisa memberikan kontribusinya bagi pembentukan sumber daya manusia yang cekatan yang dapat berkiprah di era global, dimana salah satu ciri era global adalah kompetitif. Karena itu UIN SU diharapkan menjadi lembaga pendidikan yang produknya manusia yang cerdas dan unggul.

Sebagai sebuah universitas yang baru, maka perlu dari awalnya saat sekarang dirumuskan tentang ciri khas dari lembaga ini, yang meliputi: integrited ilmu antara ilmu kewahyuan dan ilmu yang bersumber dari manusia. Selain itu upaya melakukan perubahan itu dalam praktiknya bukanlah pekerjaan yang mudah, berbagai peluang dan tantangan, serta persoalan yang tidak sedikit dibutuhkan kerja keras, kesungguhan dan komitmen bersama dalam mengelola, meningkatkan dan mengembangkannya secara berkesinambungan. 


\section{Pustaka Acuan}

Buku Profil Universitas Islam Negeri Sumatera Utara tahun 2015.

Buku Panduan Akademik IAIN Sumatera Utara Tahun Akademik 2009/2010.

Daulay, Haidar Putra. "Dinamika Pendidikan Tinggi Islam Di Indonesia (Dari Sekolah Tinggi ke Universitas)" dalam Hasan Asari, (ed.), Memperkokoh Eksistensi Memperluas Kontribusi: Antologi Tulisan Para Guru Besar Menyambut UIN SU, Medan: IAIN Press, cet. ke-1, 2015.

Daulay, Haidar Putra. Pendidikan Islam dalam Sistem Pendidikan Nasional di Indonesia, Jakarta: Kencana Prenada Media Group, cet ke-3, 2007.

Daulay, Haidar Putra. Sejarah Pertumbuhan dan Pembaruan Pendidikan Islam di Indonesia, Jakarta: Kencana Prenada Media Group, cet ke-1, 2007.

Daulay, Haidar Putra. Kapita Selekta Pendidikan Islam di Indonesia, Medan: Perdana Publishing, 2012.

Ilhamuddin, "Prospek dan Potensi Konribusi Perubahan IAIN SU Medan Menjadi UIN SU Medan Bagi Peradaban: Perspektif Ilmu Kalam" dalam Hasan Asari, (ed.), Memperkokoh Eksistensi Memperluas Kontribusi: Antologi Tulisan Para Guru Besar Menyambut UIN SU, Medan: IAIN Press, cet. ke-1, 2015.

Hasyimsyah Nasution, "Perkembangan Pemikiran dalam Islam: Kiprah UIN SU dalam Upaya Pemberdayaan Nilai" dalam Hasan Asari, (ed.), Memperkokoh Eksistensi Memperluas Kontribusi: $\quad$ Antologi Tulisan Para Guru Besar Menyambut UIN SU, Medan: IAIN Press, 2015).

Nata, Abuddin. Manajeman Pendidikan: Mengatasi Kelemahan Pendidikan Islam di Indonesia, Jakarta: Kencana Prenada Media Group, cet. ke-5, 2012.

Tafsir, Ahmad. Filsafat Pendidikan Islami: Integrasi, Rohani dan Kalbu Memanusiakan Manusia, Bandung: PT. Remaja Rosdakarya, cet. ke-3, 2008.

Tarigan, Azhari Akmal. Don't Be Chicken: Biografi Intelektual Prof. Dr. Nur A. Fadhil Lubis, MA, Medan: Perdana Publishing, cet. ke-1, 2017.

Undang-Undang Sisdiknas, UU No. 20 Tahun 2003, Departemen Agama RI, Jakarta, 2003. 
Winarni, Pembaruan Sistem Pendidikan Tinggi Islam di Indonesia: Telaah Konversi IAIN ke UIN, dalam Samsul Nizar (ed.), Sejarah Sosial dan Dinamika Intelektual Pendidikan Islam di Nusantara Jakarta: Kencana, 2013.

http://diktis.kemenag.go.id 